The Bangladesh Veterinarian (2014) 31(1): 38 - 45

\title{
Surgical affections of cattle in the milk-shed areas of Bangladesh
}

\author{
NU Sarker, K Samaddar, MM Haq and MM Rahman* \\ Department of Surgery and Obstetrics, Faculty of Veterinary Science, Bangladesh \\ Agricultural University, Mymensingh-2202, Bangladesh
}

\begin{abstract}
Little is known of the occurrence of surgical affections of cattle at the government veterinary hospitals of Bangladesh. This study was undertaken to determine the occurrence of surgical disorders in five Upazila Veterinary Hospitals (UVH) in greater Pabna administrative district. A total of 33,584 sick animals were investigated and the overall occurrence of surgical disorders is $12.9 \%$. The most common surgical affection is navel ill $(25.8 \%)$ followed by myiasis $(13.0 \%)$, foot diseases $(11.3 \%)$, arthritis $(8.8 \%)$ and teat obstruction (8.4\%). Navel ill, umbilical hernia, arthritis, horn affections, urolithiasis and tail gangrene are more common in male than female. Foot diseases, myiasis, upward patellar fixation and hip dislocation are more common in female than male. Myiasis and arthritis are found more in summer, whereas foot diseases, urolithiasis and teat crack are more common in winter. (Bangl. vet. 2014. Vol. 31, No. 1, 38 - 45)
\end{abstract}

\section{Introduction}

Livestock is the second enterprise after traditional crop agriculture in Bangladesh. About $36 \%$ of protein requirement of the people of Bangladesh is fulfilled by livestock (Ali et al., 2011). Surgical disorders are serious abnormal condition in animals and may cause fatality if not treated in time. Various violences and accidents hinder growth, performance and economic value (Hossain et al., 1986). Surgical affection like hernia, atresia ani, navel ill, myiasis, lameness and fracture cause great loss to the farmers of Bangladesh (Hossain et al., 1986). External violence produces open wounds in the skin and the incidence is common in ruminants (Nooruddin and Dey, 1990). Healing of wound is a complex biological event (Gillitzer and Goebeler, 2001) and the consequences of stress impair the tissue repairing process (Pyter et al., 2014). Myiasis constitutes a major threat to livestock industry and may occur all the year round in the tropics (Millikan, 1999). Atresia ani is the second most common surgical affection of calves in Bangladesh (Das and Hashim 1996). In addition, lameness in cattle is a serious problem and causes significant economic losses (Blowey, 1993). Contamination of umbilicus is a source of infection leading to septicemia and navel ill in neonates. Urolithiasis can also cause significant economic losses due to urethral obstruction, causing rupture of the urethra or bladder or death (Parker, 1981). There are huge grazing lands in Pabna which provide plenty of green grasses and legumes to dairy animals. In addition, indigenous Pabna breed are popular for milk production. These local breed of cow are suitably reared in Pabna. Huge milk yield is

*Corresponding author:- E-mail: miznih@gmail.com 
a common scenario in this area, that is why Pabna is called as milk-shed area of Bangladesh. However, the information of occurrence of various surgical disorders in animals is not well organized in different locations. Therefore, comprehensive survey is necessary to establish information for management of the surgical disorders in the milk-shed area of Bangladesh.

\section{Materials and Methods}

Data was collected from Pabna and Sirajgonj districts during July 2011 to June 2012, from the Upazila (Sub-districts) hospitals of Shahjadpur, Bhangura, Shanthia, Bera and Faridpur.

A total of 33,584 animals were brought to Government Veterinary Hospitals for treatment, and among them 4,332 were suffering from surgical disorders. The animals with surgical diseases were classified on the basis on sex, age and season. The study period was divided into three seasons: summer (March - June), rainy (July - October) and winter (November - February).

\section{Data analysis}

The data were checked manually for inconsistencies, recording errors or missing information. The potential errors were evaluated and corrected. Incomplete data were excluded and all completed information was analyzed in the Microsoft Excel Spreadsheet, and percentages of surgical disorders in different sex, age and seasons were calculated.

\section{Results and Discussion}

The surgical disorders in animals in Pabna district are shown in Table 1 and Fig. 1. Bera Upazilla was more prone to surgical disorders (16.7\%). Among them navel ill $(25.8 \%)$ was the highest followed by myiasis $(13.0 \%)$, foot diseases $(11.3 \%)$, arthritis $(8.8 \%)$, teat obstruction $(8.4 \%)$ and teat crack $(7.7 \%)$. Most of the animals are reared in semi-intensive or free rearing system in rural areas and are exposed to dust and mud. Newly born calves are also exposed to huge organisms, causing navel ill. The umbilicus is contaminated from wet floors, leading to septicemia in neonates (Amare, 2014). Joint ill is a common condition of calves that can cause $6 \%$ mortality in calves of Africa (Wudu et al., 2008). In contrast calves receive passive immunity by ingestion of colostrum after birth and survive with good health (Tizard, 1995).

The rate of navel ill affection is higher in male (36.7\%) than in female $(19.6 \%$; Table 2 and Fig. 2). Preputial sheath of male animal always remains moist in the umbilical region and favours umbilical infection. The occurrence of navel ill is higher in rainy season $(33.8 \%)$ followed by summer $(29.9 \%)$ and winter $(14.8 \%)$. This is probably due to muddy land, less exercise, and unhygienic floors (Huang et al., 1995). These results are similar to $12.5 \%$ umbilical affections in cattle reported by Sarker et al. (2013). However, the occurrence of navel ill in Bangladesh is near about 1\% reported earlier 
(Hossain et al., 1986). The occurrence of navel ill is reported only in younger animals at $0-1$ year of age.

Table 1. Occurrence of surgical affections of cattle in five Upazila Veterinary Hospitals of milk-shed area

\begin{tabular}{|c|c|c|c|c|c|c|c|}
\hline $\begin{array}{l}\text { Surgical } \\
\text { affection }\end{array}$ & \begin{tabular}{|c|} 
Santhia \\
$(\mathrm{n}=5483)$
\end{tabular} & $\begin{array}{c}\text { Bera } \\
(\mathrm{n}=8253) \\
\end{array}$ & $\begin{array}{l}\text { Shahjadpur } \\
(\mathrm{n}=6825)\end{array}$ & \begin{tabular}{|l|} 
Faridpur \\
$(\mathrm{n}=8539)$ \\
\end{tabular} & $\begin{array}{l}\text { Bhangura } \\
(\mathrm{n}=4484)\end{array}$ & $\begin{array}{c}\text { Total } \\
(\mathrm{n}=33584)\end{array}$ & $\begin{array}{c}\text { Total } \\
(\%)\end{array}$ \\
\hline Umbilical hernia & 20 & 74 & 56 & 10 & 25 & 185 & 4.3 \\
\hline Atresia ani & 05 & 13 & 14 & 12 & 03 & 47 & 1.1 \\
\hline $\begin{array}{l}\text { Knuckling of } \\
\text { fetlock }\end{array}$ & 02 & 08 & 05 & 00 & 03 & 18 & 0.4 \\
\hline $\begin{array}{l}\text { Upward patellar } \\
\text { fixation }\end{array}$ & 25 & 45 & 12 & 10 & 05 & 97 & 2.24 \\
\hline Dermoid cyst & 07 & 26 & 31 & 20 & 00 & 84 & 1.9 \\
\hline Navel ill & 100 & 323 & 283 & 160 & 250 & 1116 & 25.8 \\
\hline $\begin{array}{l}\text { Gangrenous } \\
\text { mastitis }\end{array}$ & 10 & 16 & 22 & 10 & 14 & 72 & 1.7 \\
\hline Teat obstruction & 40 & 93 & 72 & 120 & 40 & 365 & 8.4 \\
\hline Teat crack & 20 & 102 & 86 & 50 & 75 & 333 & 7.7 \\
\hline Tail gangrene & 08 & 17 & 18 & 10 & 00 & 53 & 1.2 \\
\hline Horn affections & 02 & 49 & 52 & 25 & 05 & 133 & 3.1 \\
\hline $\begin{array}{l}\text { Dislocation of } \\
\text { hip joint }\end{array}$ & 15 & 08 & 13 & 00 & 06 & 42 & 1.0 \\
\hline Hoof affections & 200 & 130 & 90 & 20 & 50 & 490 & 11.3 \\
\hline Fracture & 00 & 12 & 28 & 36 & 03 & 79 & 1.8 \\
\hline Myiasis & 150 & 215 & 65 & 100 & 35 & 565 & 13.0 \\
\hline Urolithiasis & 80 & 72 & 35 & 48 & 35 & 270 & 6.2 \\
\hline Arthritis & 31 & 173 & 24 & 130 & 25 & 383 & 8.8 \\
\hline Total & $\begin{array}{c}715 \\
(13.0 \%) \\
\end{array}$ & $\begin{array}{c}1376 \\
(16.7 \%) \\
\end{array}$ & $\begin{array}{c}906 \\
(13.3 \%) \\
\end{array}$ & $\begin{array}{c}761 \\
(8.9 \%) \\
\end{array}$ & $\begin{array}{c}574 \\
(12.8 \%) \\
\end{array}$ & $\begin{array}{c}4332 \\
(12.9 \%) \\
\end{array}$ & 100 \\
\hline
\end{tabular}

$\mathrm{n}=$ number of cattle

1 Occurrence of surgical affections in cattle in five Upazila Veterinary Hospital



$\square$ Umbilical hernia

$\square$ Atresia ani

$\square$ Knuckling of fetlock

$\square$ Upward patellar fixation

$\square$ Dermoid cyst

$\square$ Navel ill

$\square$ Gangrenous mastitis

$\square$ Teat obstruction

- Teat crack

$\square$ Tail gangrene

$\square$ Horn affections

$\square$ Dislocation of hip joint

- Foot diseases

- Fracture

$\square$ Myiasis

- Urolithiasis

Fig. 1. Percentage of surgical affections of cattle in five Upazila Veterinary Hospitals of milk-shed area 
Table 2. Surgical affections occurring in different sex of cattle in milk-shed area

\begin{tabular}{|c|c|c|c|c|c|}
\hline \multirow[t]{2}{*}{ Name of affections } & \multicolumn{2}{|c|}{ Male $(\mathrm{n}=1780)$} & \multicolumn{2}{|c|}{ Female $(\mathrm{n}=2552)$} & \multirow{2}{*}{$\begin{array}{c}\text { Total } \\
(\mathrm{n}=4332) \\
(\%)\end{array}$} \\
\hline & Number & $\begin{array}{c}\text { Occurrence } \\
(\%)\end{array}$ & Number & $\begin{array}{c}\text { Occurrence } \\
(\%)\end{array}$ & \\
\hline Umbilical hernia & 136 & 7.6 & 49 & 1.9 & $185(4.3)$ \\
\hline Atresia ani & 37 & 2.1 & 10 & 0.4 & $47(1.1)$ \\
\hline Knuckling of fetlock & 11 & 0.6 & 7 & 0.3 & $18(0.4)$ \\
\hline Upward patellar fixation & 34 & 1.9 & 63 & 2.5 & $97(2.2)$ \\
\hline Dermoid cyst & 57 & 3.2 & 27 & 1.1 & $84(1.9)$ \\
\hline Navel ill & 617 & 34.7 & 499 & 19.6 & $1116(25.8)$ \\
\hline Gangrenous mastitis & 0 & 0.0 & 72 & 2.8 & $72(1.7)$ \\
\hline Teat obstruction & 0 & 0.0 & 365 & 14.3 & $365(8.4)$ \\
\hline Teat crack & 0 & 0.0 & 333 & 13.1 & 333(7.7) \\
\hline Tail gangrene & 41 & 2.3 & 12 & 0.5 & $53(1.2)$ \\
\hline Horn affections & 101 & 5.7 & 32 & 1.3 & 133(3.1) \\
\hline Dislocation of hip & 3 & 0.2 & 39 & 1.5 & $42(1.0)$ \\
\hline Hoof affections & 117 & 6.6 & 373 & 14.6 & $490(11.3)$ \\
\hline Fracture & 17 & 1.0 & 62 & 2.4 & $79(1.8)$ \\
\hline Myiasis & 207 & 11.6 & 358 & 14.0 & $565(13.0)$ \\
\hline Urolithiasis & 270 & 15.2 & 0 & 0 & $270(6.2)$ \\
\hline Arthritis & 166 & 9.3 & 217 & 8.5 & $383(8.8)$ \\
\hline Total affections & 1780 & 41.1 & 2552 & 58.9 & 4332 \\
\hline
\end{tabular}

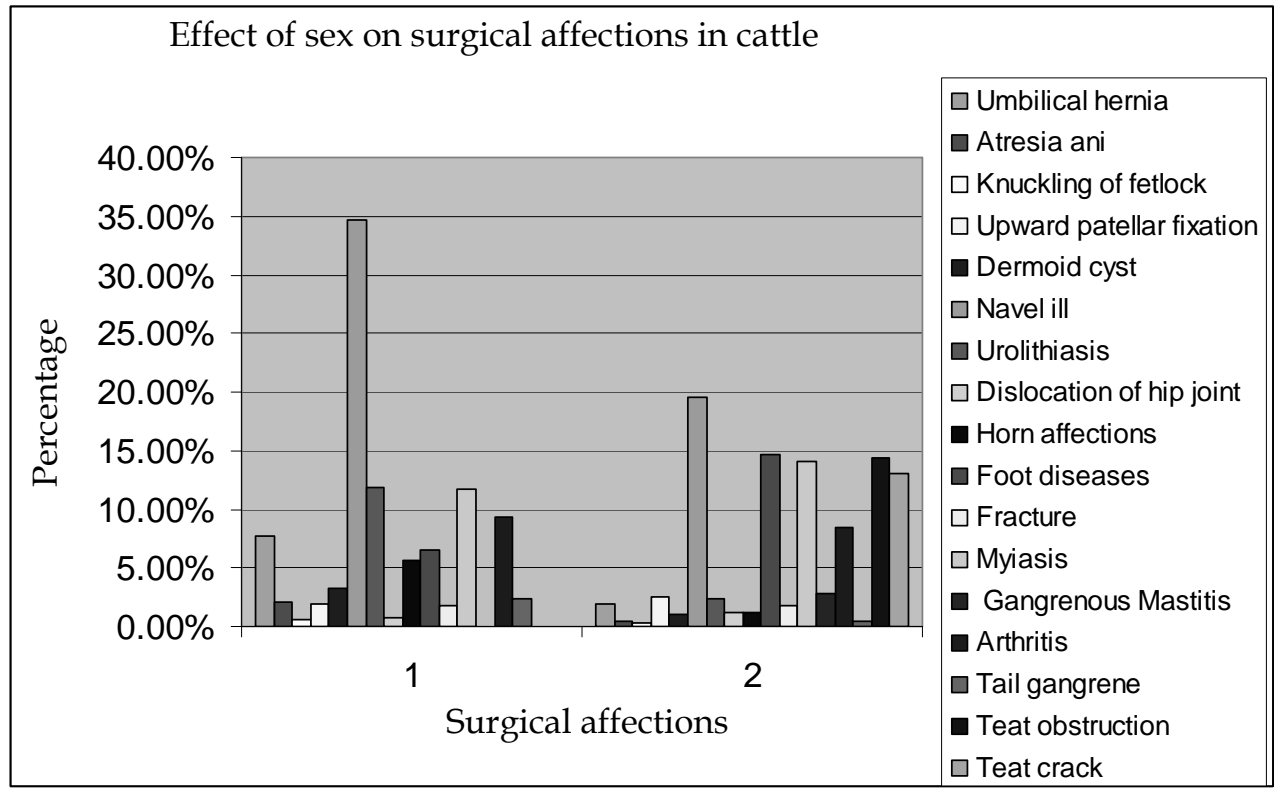

Fig. 2. Effects of sex on surgical affections in cattle in milk-shed area 
Myiasis is the second most prevalent surgical disorder (13.0\%) in this study. Animals reared in semi-intensive or free rearing system in rural area are easily exposed to flies. Moreover, summer is the most favourable season for the breeding of flies. It is also reported that the number of larvae is higher in spring, and then decreasing in autumn (Arslan et al., 2009). The huge number of flies contributes to the production of large number of maggots which are a threat to life (Kaul, 2011). The affection rate is very close to male $(11.6 \%)$ and female $(14.0 \%)$ in this study. However, lower infestation rate has been reported by previous investigator (Sarker et al., 2013). Moreover higher $(20.9 \%)$ rate of myiasis has been seen in summer than winter $(2.8 \%)$ (Table 3$)$. The result is closely related to the finding of Arslan et al. (2009).

Table 3. Effects of season on surgical affections in cattle of milk-shed area

\begin{tabular}{l|ccc|c|c|c|c}
\hline \multirow{2}{*}{ Affection } & \multicolumn{2}{c|}{$\begin{array}{c}\text { Summer } \\
(\mathrm{n}=1997)\end{array}$} & \multicolumn{2}{c|}{$\begin{array}{c}\text { Rainy season } \\
(\mathrm{n}=952)\end{array}$} & \multicolumn{2}{c|}{$\begin{array}{c}\text { Winter } \\
(\mathrm{n}=952)\end{array}$} & $\begin{array}{c}\text { Total } \\
\text { affection }\end{array}$ \\
\cline { 2 - 7 } & Number & $\%$ & Number & $\%$ & Number & $\%$ & \\
\hline Umbilical Hernia & 102 & 5.1 & 43 & 4.5 & 40 & 2.9 & 185 \\
Atresia ani & 31 & 1.6 & 9 & 1.0 & 7 & 0.5 & 47 \\
Knuckling of fetlock & 5 & 0.3 & 4 & 0.4 & 9 & 0.7 & 18 \\
Upward patellar & 31 & 1.6 & 23 & 2.4 & 43 & 3.1 & 97 \\
fixation & & & & & & & \\
Dermoid cyst & 43 & 2.2 & 27 & 2.8 & 14 & 1.0 & 84 \\
Navel ill & 597 & 29.9 & 315 & 33.1 & 204 & 14.8 & 1116 \\
Gangrenous mastitis & 37 & 1.9 & 18 & 1.9 & 17 & 1.2 & 72 \\
Teat obstruction & 93 & 4.7 & 67 & 7.0 & 205 & 14.8 & 365 \\
Teat crack & 73 & 3.7 & 47 & 4.9 & 213 & 15.4 & 333 \\
Tail gangrene & 17 & 0.9 & 28 & 2.9 & 8 & 0.6 & 53 \\
Horn affections & 89 & 4.5 & 27 & 2.8 & 17 & 1.2 & 133 \\
Dislocation of hip & 22 & 1.1 & 13 & 1.4 & 7 & 0.5 & 42 \\
Hoof affections & 113 & 5.7 & 83 & 8.7 & 294 & 21.3 & 490 \\
Fracture & 47 & 2.4 & 7 & 0.7 & 25 & 1.8 & 79 \\
Myiasis & 417 & 20.9 & 109 & 11.4 & 39 & 2.8 & 565 \\
Urolithiasis & 87 & 4.4 & 56 & 5.9 & 127 & 9.2 & 270 \\
Arthritis & 193 & 9.7 & 76 & 8.0 & 114 & 8.2 & 383 \\
\hline Total & 1997 & & 952 & & 1383 & & 4332 \\
\hline
\end{tabular}

Hoof affection is the third most common surgical disorder in cattle. The incidence of hoof affections is higher in the winter $(21.3 \%)$ than rainy season $(8.7 \%)$ and summer $(5.7 \%)$. It is due to outbreak of foot and mouth disease, muddy land, less exercise, and 
unhygienic floor (Huang et al., 1995). The occurrence of hoof affection is higher in cows considering the sex. Prevalence of foot disease is higher in male than in female (Noman et al., 2013). Cows of Pabna region are mostly crossbred with Zebu and Holstein-Friesian. Heavy weight of cow may cause chronic laminitis, sub-acute laminitis and heel horn erosion.

Urolithiasis is recorded $6.2 \%$ in cattle in this present investigation. Samad (2001) reported very low percentage $(0.02 \%)$ of obstructive urolithiasis in animal. The percentage of urolithiasis is higher in male $(11.9 \%)$ than female $(2.3 \%)$, due to structural difference of urinary tract. This result agrees with recent findings of urolithiasis in Pabna by Kibria (2010). It may be due to unavailability of green grass, and high concentrate diet, or imbalanced intake of minerals (Hesse et al., 2009). Some concentrates have high levels of phosphorous and magnesium but relatively low calcium and potassium, which predisposes to the condition. The occurrence of urolithiasis is higher in winter $(9.2 \%)$ than summer $(4.4 \%)$ (Table 3). It may be due to scarcity of green grass and lower intake of water in winter.

The surgical affections related to different ages are recorded in Table 4 . The occurrence of navel ill is $67.4 \%$ in animals under one year. The high incidence of navel ill is due to unhygienic management of newborn. On the other hand the occurrence of dislocation of hip, atresia ani, knuckling of fetlock, tail gangrene, dermoid cyst and horn affections is low.

Table 4. Effects of age on surgical affections in cattle of milk-shed area

\begin{tabular}{l|ccc|cc|ccc|c}
\hline \multirow{2}{*}{ Name of affections } & \multicolumn{2}{|c|}{ Age 0-1 year } & \multicolumn{2}{c|}{ Age 1-3 year } & \multicolumn{2}{c|}{ Age > 3 years } & Total \\
\cline { 2 - 7 } & Number & $\%$ & Number & $\%$ & Number & $\%$ & affection \\
\hline Umbilical hernia & 127 & 7.7 & 53 & 5.6 & 5 & 0.3 & 185 \\
Atresia ani & 47 & 2.8 & - & - & - & - & 47 \\
Knuckling of fetlock & 18 & 1.1 & - & - & - & - & 18 \\
Upward patellar & - & - & 23 & 2.6 & 74 & 4.1 & 97 \\
fixation & & & & & & & \\
Dermoid cyst & 79 & 4.8 & 5 & 0.6 & - & - & 84 \\
Navel ill & 1116 & 67.4 & - & - & - & - & 1116 \\
Gangrenous mastitis & - & - & - & - & 72 & 4.0 & 72 \\
Teat obstruction & - & $\%$ & 109 & 12.3 & 256 & 14.3 & 365 \\
Teat crack & - & - & 47 & 5.3 & 286 & 16.0 & 333 \\
Tail gangrene & - & - & 13 & 1.5 & 40 & 2.2 & 53 \\
Horn affections & - & - & 34 & 3.9 & 99 & 5.5 & 133 \\
Dislocation of hip & - & - & 3 & 0.3 & 39 & 2.2 & 42 \\
Foot diseases & 31 & 1.9 & 153 & 17.3 & 306 & 17.1 & 490 \\
Fracture & 7 & 0.4 & 21 & 2.4 & 51 & 2.8 & 79 \\
Myiasis & 103 & 6.2 & 161 & 18.2 & 301 & 16.8 & 565 \\
Urolithiasis & - & - & 161 & 18.2 & 109 & 6.1 & 270 \\
Arthritis & 127 & 7.7 & 101 & 11.4 & 155 & 8.6 & 383 \\
\hline Total & 1655 & - & 884 & - & 1793 & - & 4332 \\
\hline
\end{tabular}


Highest occurrence of navel ill followed by myiasis, hoof affections and arthritis has been recorded in different age and seasons. Summer and rainy season are the time when the occurrence of navel ill is higher, and then myiasis. As the Pabna breed is the larger indigenous breed and the affection causing lameness including the arthritis and hoof disorders make the animal unable to graze in pasture and are confined in shed. It is impossible to move the animal to nearby veterinary hospital. So early diagnosis and surgical intervention in field condition are necessary for the recovery. It is concluded that early diagnosis and estimation of occurrence of the surgical affection is important for rapid surgical treatment. It could be an index for the salvage and development of cattle population in Pabna milk-shed area.

\section{References}

Amare Y 2014: Umbilical cord care in Ethiopia and implications for behavioral change: a qualitative study. BMC International Health and Human Rights 1412.

Ali MH, Bhuiyan MKJ, Alam MM 2011: Retrospective epidemiologic study of diseases in ruminants in Khagrachari hill tract district of Bangladesh. Bangladesh Journal of Veterinary Medicine 9 145-153.

Arslan MO, Kara M, Gicik Y 2009: Epidemiology of Oestrus ovis infestations in sheep in Kars province of north-eastern Turkey. Tropical Animal Health and Production $\mathbf{4 1}$ 299-305.

Blowey RW 1993: Common diseases of the foot. Cattle lameness and hoof care. Farming Press, Ipswich, United Kingdom. pp. 39-55.

Das BR, Hashim MA 1996: Studies on surgical affections in calves. Bangladesh Veterinary Journal 30 53-57.

Gillitzer R, Goebeler M 2001: Chemokines in cutaneous wound healing. Journal of Leukocyte Biology 69 513-521.

Hesse AT, Tiselius HG, Siener R 2009: Urinary Stones Diagnosis, Treatment and Prevention of Recurrence. Karger (Editor), ISBN 978-3-8055-9149-2.

Hossain MA, Shahidullah M, Ali MA 1986: Surgical disease and reproductive disorders recorded at the Veterinary Hospital of Bangladesh Agricultural University, Mymensingh, Bangladesh. Bangladesh Veterinary Journal 20 1-5.

Huang J, Offer JE, Hyslop JJ 1995: The cow and her cubicle. Proceeding of the $5^{\text {th }}$ International Symposium on Disease of the Ruminant Digit. Journal of the British Veterinary Association 7 276-278.

Kaul R 2011: "Doctors remove 100 live maggots from a 75-year-old woman's nose". Hindustan Times 13 24-26.

Kibria AS 2010: A comparative study on prevalence of various clinical diseases and disorders of cattle and goat in Pabna district. MS Thesis, Department of Medicine, Bangladesh Agricultural University, Mymensingh. 
Millikan L 1999: Myiasis. Clinics in Dermatologic 17 191-195.

Noman ASM, Juyena NS, Alam MM, Ferdousy RN, Paul S, Haq MM 2013: Prevalence of surgical affections of cattle in Aarong Dairy Area of Pabna. Progressive Agriculture 24 85-92.

Nooruddin M, Dey AS 1990: Further study on the prevalence of skin disease in domestic ruminants in Bangladesh. Bangladesh Veterinarian 4 5-9.

Parker BN 1981: Urolithiasis in calves and lambs. The Veterinary Record 108 545-546.

Pyter LM, Yang L, McKenzie C, Rocha JM, Carter CS, Cheng B, Engeland CG 2014: Contrasting mechanisms by which social isolation and restraint impair healing in male mice. Stress 17 256-265.

Samad MA 2001: Observations of clinical diseases in ruminants at the Bangladesh Agricultural University Veterinary Clinic. Bangladesh Veterinary Journal 35 93-120.

Sarker NU, Rahman MM, Rana MS, Islam MT, Rima UK 2013: Prevalence of surgical diseases of cattle in stall-fed and free-range cattle in Bangladesh. Bangladesh Veterinarian 30 62-69.

Tizard I 1995: Veterinary Immunology $4^{\text {th }}$ ed. WB Saunders Company, Philadelphia, USA.

Wudu T, Kelay B, Mekonnen HM, Tesfu K 2008: Calf morbidity and mortality in smallholder dairy farms in Ada'a Liben district of Oromia, Ethiopia. Tropical Animal Health and Production 40 369-376. 